\title{
ANATOMICAL CHARACTERIZATION OF TENSION WOOD IN Hevea brasiliensis (Willd. ex A. Juss.) Mull. Arg. ${ }^{1}$
}

\author{
Letícia Maria Alves Ramos², João Vicente de Figueiredo Latorraca ${ }^{3 *}$, Thayanne Caroline Castor Neto ${ }^{4}$, \\ Letícia Souza Martins ${ }^{4}$ and Elias Taylor Durgante Severo ${ }^{5}$
}

\footnotetext{
${ }^{1}$ Received on 02.04.2016 accepted for publication on 26.09.2016.

${ }^{2}$ Universidade Federal Rural do Rio de Janeiro, Programa de Pós-Graduação em Ciências Ambientais e Florestais, Seropédica, Rio de Janeiro - Brasil. E-mail: <leticiaalves.ramos@hotmail.com>.

${ }^{3}$ Universidade Federal Rural do Rio de Janeiro, Instituto de Florestas, Departamento de Produtos Florestais, Seropédica, Rio de Janeiro - Brasil. E-mail: <latorraca@hotmail.com>.

${ }^{4}$ Universidade Federal Rural do Rio de Janeiro, Graduanda em Engenharia Florestal, Seropédica, Rio de Janeiro - Brasil. E-mail: <neto.thayanne@gmail.com> and <lelesmartins@hotmail.com>.

${ }^{5}$ Universidade Estadual Paulista Júlio de Mesquita Filho, Departamento de Ciência Florestal, Botucatu, São Paulo - Brasil. E-mail: <severo@fca.unesp.br>.

*Corresponding author.
}

\begin{abstract}
Tension wood is an important anatomical structure for its participation in the orientation of the trunk and the architecture of the branches as a function of structural reinforcement. However, its presence in large amounts significantly affects the technological properties of wood, just as in the rubber tree. Nevertheless, there is still demand for information about the origin, distribution and structural features in this species. Thus, this study aims to characterize the cellular structures in tension and opposite wood in Hevea brasiliensis (rubber tree), as well as its radial and longitudinal distribution. Discs at the base and the middle of the commercial logs were collected from three trees in a commercial plantation located in Tabapoã - SP. Tangential diameter of vessels, fiber length (gelatinous and non-gelatinous fibers), microfibril angle and proportionality of cellular elements (vessels, axial parenchyma, ray, gelatinous fibers and nongelatinous fibers) were measured, and influence of gelatinous fiber presence in vessel diameter was observed. Gelatinous fibers were observed in the two types of wood and in the two trunk heights. Both types of wood were distinguished by gelatinous fiber length and the proportion of axial parenchyma. The tension wood in mid-trunk was the most different, with long gelatinous fibers and less abundant, larger vessel diameter and vessel proportion. Moreover, smaller vessel diameter was observed in the regions with a high proportion of gelatinous fibers, suggesting that the plant invests more support than in liquid transport.
\end{abstract}

Keywords: Tension wood; Rubber tree; G-fibers

\section{CARACTERIZAÇÃO ANATÔMICA DO LENHO DE TRAÇÃO EM Hevea brasiliensis (Willd. ex A. Juss.) Mull. Arg.}

RESUMO - O lenho de tração é uma estrutura anatômica importante, que permite a reorientação do tronco e participa na arquitetura dos ramos, tendo a função de reforço estrutural. Contudo, sua presença em grande quantidade afeta significativamente as propriedades tecnológicas da madeira, como no caso da seringueira. Entretanto, ainda há demanda de informações acerca de sua origem, distribuição e características estruturais nessa espécie. Portanto, esse trabalho objetivou caracterizar as estruturas celulares no lenho de tração e lenho oposto em Hevea brasiliensis (seringueira) e sua distribuição radial e longitudinal. Para tanto, discos da base e do meio do fuste comercial foram coletados de três árvores provenientes de um plantio comercial localizado em Tabapoã - SP. Foram mensurados o diâmetro tangencial dos elementos de vaso, comprimento de fibras (gelatinosas e não-gelatinosas), ângulo microfibrilar e proporcionalidade de elementos celulares, e a relação entre a presença de fibras gelatinosas e o diâmetro de vasos. Foram observadas fibras gelatinosas nos dois tipos de lenho e nas duas alturas do fuste avaliadas. Os dois tipos de lenho foram diferenciados pelo comprimento de fibras gelatinosas e a proporção de parênquima axial. A região de tração no meio do fuste foi a que mais 
se diferenciou das demais, com fibras gelatinosas mais compridas e menos abundante, maiores diametro e proporção de vasos. Além disso, foi observado menor diâmetro de vasos nas regiões com alta proporção de fibras gelatinosas, sugerindo que a planta investe mais em sustentação que na condução de líquidos.

Palavras-chave: Lenho de reação; Seringueira; Fibras gelatinosas

\section{INTRODUCTION}

Wood presents variations in its technological properties according to its structural direction, which may have genotypic or phenotypic origin. The formation of reaction wood is one of the most important changes in wood, and in Angiosperms it is known as tension wood.

Tension wood is often defined as a specialized tissue that can force the trunk and branches of the tree to maintain a certain orientation, being assigned to the reorientation function of the trunk and branch architecture (FISHER; STEVENSON, 1981). However, it can also be observed in upright/straight trunks (CÔTÉ; DAY; TIMELL, 1969), and this fact brings into question the function of reestablishing the trunk's position (FOURNIER et al., 2014).

In many angiosperm species, the main characteristic of this type of wood is the presence of long fibers which have a thick cellulose layer in its interior known as gelatinous layer, almost entirely filling the lumen (DÉJARDIN et al., 2010). This layer provides particular biochemical, mechanical and ultrastructural characteristics (PRAMOD et al., 2013).

The tension wood in hardwoods is often seen macroscopically by the trunk eccentricity at the cross section, suggesting that there is a higher cell production in the tensioned region so that it has a larger radial growth (DÉJARDIN et al., 2010). Consequently, the pith/core is displaced from its natural position, known as 'pith eccentricity'. The portion of the trunk with the lowest radial growth located in the area opposite to the tension wood receives the name 'opposite wood'.

Despite tension wood's physiological importance, its presence in large quantities contributes to the low yield in wood processing, which may restrict its use (RATNASINGAM; MA, 2010). Jourez (1997) considers tension wood as a complex physiological phenomenon, which varies according to the species in which there is interaction of various stimuli and changes in the structure and composition of wood, relating to growth stresses.
It is common to observe the presence of tension wood in rubber trees (LIM, 1998; NOBUCHI et al., 2011), as well as in other species of the Euphorbiaceae family (LUCHI, 2004; NASSAR et al., 2010; SIEGLOCH et al., 2013; NAKAGAWA et al., 2014). Due to this fact, several studies have been developed in order to overcome related problems, such as low natural durability and dimensional instability (MATAN; MATAN; KETSA, 2012; SHUKLA; SHARMA, 2014; RATNASINGAM; GROHMANN, 2015).

Brazil has no tradition of using wood from rubber trees. However, it has rubber plantations close to the decline of the latex production phase which can serve as an option to supply the timber industry (OKINO et al., 2004). Nevertheless, the wood from rubber trees in Brazil is still used as biomass for furnaces and boilers (CONEGLIAN; SEVERO, 2014).

The lack of information on the structural characteristics of wood to help in understanding tension wood biosynthesis in wood from rubber trees is still perceptible. In this sense, the present study aimed at characterizing the anatomical structure of rubber tree tension wood by way of investigating the differences between the cell characteristics of this wood and opposite wood in the base and middle trunk regions.

\section{MATERIAL AND METHODS}

\subsection{Sample}

Three 53-year-old Hevea brasiliensis (Willd. exA. Juss.) Mull. Arg. trees with diameters of approximately $45 \mathrm{~cm}$ were collected from a plantation located at Fazenda Água Milagrosa - Tabapoã, in São Paulo, Brazil. Of these, three disks were removed from the trunk base and three others at 50\% (middle) trunk height. This material was then deposited into the wood collection of the Forest Institute of the Rural Federal University of Rio de Janeiro according to the following registration numbers: tree $1-7603$ and 7604 ; tree $2-7605$ and 7606 ; tree $3-7607$ and 7608 . 


\subsection{Preparation of the samples}

From the pith position, diametric sections of the representative tension and opposite wood regions were selected for body specimen cut in the intermediate region of the radius (between the pith and bark) of both regions. Histological sections were sectioned in the cross-sectional planes by sliding microtome MICRON HM 450 with an average thickness of $18 \mu \mathrm{m}$ were obtained to locate the gelatinous fibers, to measure the tangential diameter of vessel elements and to determine the proportions of cell elements. The obtained sections were stained with aqueous $1 \%$ Safranin and $1 \%$ Astra Blue (6: 4) (BUKATSCH, 1972), in order to produce semi-permanent slides.

The remaining material of the specimens was dissociated in a solution of glacial acetic acid and hydrogen peroxide (1:1) for approximately 12 hours in a heater plate under a fume hood to determine fiber lengths. After dissociation, the fibers were stained with safranin (1\%). Histological sections with a thickness of $10 \mathrm{ìm}$ were also dissociated according to the same process to measure microfibril angle.

\subsection{Measurements}

Tangential vessel diameters for both wood types were measured at the base discs and mid-trunk. The diameter of vessel elements was also measured in regions with and without predominance of gelatinous fibers, regardless of the type of wood or location on the trunk. Furthermore, the proportion of anatomical elements and their radial variation in tension and opposite wood were determined. For this, the number of vessels, radii, axial parenchyma, non-gelatinous fibers and gelatinous fibers in an area of $2.54 \mathrm{~mm}^{2}$ were counted, with 2-3 repetitions per histological section. A grid (mesh) was applied using the Image-Pro Plus ${ }^{\circledR}$ program, covering 204 points of each analyzed image. The points where cellular elements were found were marked and their proportions were calculated in relation to the total of 204 points.

The length of the non-gelatinous and gelatinous fibers were measured in the dissociated cells in the tension and opposite wood at both trunk heights $(n=25)$. The microfibril angle was measured with the aid of a polarized light microscope. This apparatus is equipped with a graduated turntable from $0^{\circ}$ to $360^{\circ}$, on which the slides were placed in a way so that the fibers stayed in the vertical position and light passage was not interrupted. Then, the table was rotated until the fibers were under extinguished light position and the displayed angle was recorded. Angles of 25 fibers were measured in both types of wood, and for each radial region.

\subsection{Data analysis}

In analyzing the anatomical variables, there was a difference verified between tension and opposite wood regions in the base discs and at mid-trunk. These regions comprise the variable named 'group'. An additional analysis of the tangential diameter of vessels was also performed in which the data were separated according to regions of predominantly gelatinous fibers and predominantly non-gelatinous fibers, as well as at the base and at mid-trunk, regardless of the wood type. The experimental design is presented in Table 1.

Table 1 - Experimental design.

Tabela 1 -Desenho experimental.

\begin{tabular}{lccc}
\hline Analysis & Group & \multicolumn{2}{c}{ Description } \\
\cline { 3 - 4 } & & Steam region & Disc Region / Histological section \\
\hline Anatomical & BLR & Base & Larger radius ("Tension wood") \\
variables & BLO & Base & Smaller radius ("Opposite wood") \\
(Multivariate) & MLR & Middle & Sarger radius ("Tension wood") \\
& MLO & Base & Gelatinous fibers \\
Tangential & BFG & Base & Non-gelatinous fibers \\
diameter of & BSF & Middle & Gelatinous fibers \\
the Vessels & MFG & Middle & Non-gelatinous fibers \\
(ANOVA) & MSFG & M copposite wood") \\
\hline
\end{tabular}

$\mathrm{BLR}=$ reaction wood in the base; $\mathrm{BLO}=$ opposite wood in the base; $\mathrm{MLR}=$ reaction wood in the middle; $\mathrm{MLO}=\mathrm{opposite}$ wood in the middle; $\mathrm{BFG}=$ gelatinous fiber in the base; $\mathrm{BSFG}=$ non-gelatinous fiber in the base; $\mathrm{MFG}=$ gelatinous fiber in the middle; $\mathrm{MSFG}=$ non-gelatinous fiber in the middle.

$B L R=$ lenho de reação na base; $B L O=$ lenho oposto na base; $M L R=$ lenho de reação no meio; $M L O=$ lenho oposto no meio; $B F G=$ fibra gelatinosa na base; BSFG =fibra não-gelatinosa na base; MFG=fibra gelatinosa no meio; MSFG=fibra não-gelatinosa no meio. 
All anatomical variables were primarily analyzed with the use of MANOVA (or multifactor ANOVA) to evaluate the effect of the variable 'group'. When there was significance, the analysis continued using Hochberg's GT2 test due to differences in sample size, and with a $5 \%$ probability, in order to identify which variables were responsible for the significant effect. Moreover, these variables were grouped by the technical Two Step cluster analysis in order to create homogeneous groups based on their common characteristics. Multiple variables represented by anatomical characteristics were analyzed in combination with the variable 'group', allowing for the creation of subprofiles with similar characteristics.

For additional assessment of the tangential vessel diameter, the data were analyzed using oneway ANOVA in order to evaluate whether the presence of gelatinous fibers positively or negatively influences vessels' diameter. If significance was found, the analysis continued with the Hochberg's GT2 test with a significance level of $5 \%$.

\section{RESULTS}

This study analyzed the cellular characteristics of tension and opposite wood in rubber trees. The results showed that structural differences between the woods can be identified based on the characteristics of the evaluated variables.

The application of MANOVA generally showed that there is a significant effect of the independent variable on the dependent variables such as group by the Wilks' » test $[0.432$, with $\mathrm{F}(27 ; 172.95)=2.13$, $\mathrm{p}=0.02<0.05]$. The univariate result showed that significant effects were caused by the gelatinous fiber length and the axial parenchyma ratio $[\mathrm{F}=3.66, \mathrm{p}=0.02$ $<0.05 ; \mathrm{F}=3.60, \mathrm{p}=0.02<0.05]$.

Table 2 shows results of descriptive statistics and Hochberg's GT2 test for the variables in the sampled regions (groups), which represent two types of wood at two trunk heights. Tension wood at 50\% trunk height (MLR) stood out for presenting the highest gelatinous fiber lengths, larger diameters and higher proportion of vessels, axial parenchyma and non-gelatinous fibers. However, the proportion of gelatinous fibers was the lowest among all groups, while the opposite wood at the same trunk height (MLO) had the smallest vessel diameters and the highest proportion of gelatinous fiber, and consequently, a lower proportion of nongelatinous fiber.

Two comparisons had significant effects $(p<0.05)$. These effects are related to BLR and MLR groups for gelatinous fiber length, and between MLR and BLO groups for the axial parenchyma ratio (Table 2).

In the Two Step cluster analysis, all continuous variables and the 'group' variable were investigated and divided into two clusters. The first cluster grouped most of the sampled cases $(63 \%)$, comprising $92.9 \%$ of the observations in BLO, $86.4 \%$ in BLR, $100 \%$ in MLO and $0 \%$ in MLR. On the other hand, the second cluster comprised only $7.1 \%$ of the observations in BLO, $13.6 \%$ in BLR, $0 \%$ in MLO and $100 \%$ in MLR. This result shows that at mid-trunk, tension wood was the region that most differed from the others regarding the observed characteristics, placing it virtually isolated in cluster 2 .

Table 3 shows cluster centers, which are the average values of the variables used to define each cluster. Cluster 1 was characterized by gelatinous fibers of greater length and a greater proportion of smaller diameter vessels and a lower proportion of non-gelatinous fibers. Cluster 2, on the other hand, is characterized by shorter length and smaller proportion gelatinous fibers, larger diameter vessels and smaller proportion of non-gelatinous fibers. The other variables showed similar values between the formed clusters.

The variables were classified according to their significance within the clusters (Figure 1). A significant cluster must have at least one significant variable. For both clusters, the variable group was the significant variable. In cluster 1, only the proportion of nongelatinous fiber and the proportion of gelatinous fiber were statistically significant, being the two most important variables. Despite cluster 2 not presenting significant variables, the four most important variables within each cluster were the same - proportion of gelatinous and non-gelatinous fibers, proportion of vessel elements and length of gelatinous fibers - however, they were not in the same order of importance.

One-way ANOVA was conducted in order to verify the effect of the presence of gelatinous fibers in the tangential diameter of vessel elements in four regions of the trunk, represented by four groups. The analysis showed significant differences between groups, and reinforced what was observed in the previous analysis. 
Table 2 - Descriptive statistics for the anatomical variables within groups.

Tabela 2 - Estatísticas descritivas para as variáveis anatômicas dentro dos grupos.

\begin{tabular}{|c|c|c|c|c|c|c|c|c|c|c|c|}
\hline \multirow[t]{2}{*}{ Groups } & & \multicolumn{10}{|c|}{ Variables } \\
\hline & & $\begin{array}{l}\text { Len. } \\
\text { FN } \\
(\mu \mathrm{m})\end{array}$ & $\begin{array}{c}\text { Len. FG } \\
\text { FG } \\
(\mu \mathrm{m})\end{array}$ & $\begin{array}{c}\text { MFA } \\
\left(^{\circ}\right)\end{array}$ & $\begin{array}{l}\text { Vessel } \\
\text { diam. } \\
(\mu \mathrm{m})\end{array}$ & $\begin{array}{l}\text { Prop. } \\
\text { Vessel } \\
(\%)\end{array}$ & $\begin{array}{l}\text { Prop. } \\
\text { RP } \\
(\%)\end{array}$ & $\begin{array}{l}\text { Prop. } \\
\text { AP } \\
(\%)\end{array}$ & $\begin{array}{l}\text { Prop. } \\
\text { NF } \\
(\%)\end{array}$ & $\begin{array}{l}\text { Prop. } \\
\text { GF } \\
(\mu \mathrm{m})\end{array}$ & $\begin{array}{l}\text { Len. } \\
\mathrm{NF} \\
(\mu \mathrm{m})\end{array}$ \\
\hline \multirow[t]{4}{*}{ BLR } & Min. & 1150.8 & 1196.4 & 15 & 144.5 & 4.4 & 13.7 & 8.4 & 1.0 & 2.0 & 1150.8 \\
\hline & Max. & 1377.1 & 1433.1 & 24 & 199.0 & 15.7 & 22.6 & 21.1 & 52.9 & 62.0 & 1377.1 \\
\hline & Mean & $1253.2^{\mathrm{a}}$ & $1292.8^{\mathrm{a}}$ & $21^{\mathrm{a}}$ & $173.2^{\mathrm{a}}$ & $8.4^{\mathrm{a}}$ & $18.7^{\mathrm{a}}$ & $14.2^{\mathrm{ab}}$ & $15.4^{\mathrm{a}}$ & $43.4^{\mathrm{a}}$ & $1253.2^{\mathrm{a}}$ \\
\hline & C.V. (\%) & 5.0 & 4.9 & 12 & 9.0 & 33.8 & 9.8 & 24.0 & 95.8 & 39.1 & 5.0 \\
\hline \multirow[t]{4}{*}{ BLO } & Min. & 1139.8 & 1219.9 & 16 & 141.1 & 3.9 & 13.2 & 9.8 & 0.0 & 13.2 & 1139.8 \\
\hline & Max. & 1412.1 & 1483.0 & 22 & 203.9 & 11.5 & 27.7 & 20.1 & 44.6 & 66.8 & 1412.1 \\
\hline & Mean & $1251.7^{\mathrm{a}}$ & $1313.0^{\mathrm{ab}}$ & $20^{\mathrm{a}}$ & $172.0^{\mathrm{a}}$ & $7.7^{\mathrm{a}}$ & $18.4^{\mathrm{a}}$ & $13.5^{\mathrm{a}}$ & $14.2^{\mathrm{a}}$ & $46.1^{\mathrm{a}}$ & $1251.7^{\mathrm{a}}$ \\
\hline & C.V. (\%) & 6.2 & 4.9 & 10 & 11.2 & 27.0 & 21.3 & 18.7 & 84.6 & 31.0 & 6.2 \\
\hline \multirow[t]{4}{*}{ MLR } & Min. & 1055.5 & 1210.9 & 13 & 143.4 & 5.4 & 11.8 & 12.3 & 2.0 & 0.0 & 1055.5 \\
\hline & Max. & 1421.4 & 1495.9 & 26 & 234.1 & 14.2 & 21.6 & 20.1 & 58.8 & 56.4 & 1421.4 \\
\hline & Mean & $1232.9^{a}$ & $1357.5^{\mathrm{b}}$ & $20^{\mathrm{a}}$ & $184.2^{\mathrm{a}}$ & $9.7^{\mathrm{a}}$ & $17.0^{\mathrm{a}}$ & $16.3^{\mathrm{b}}$ & $19.1^{\mathrm{a}}$ & $38.0^{\mathrm{a}}$ & $1232.9^{\mathrm{a}}$ \\
\hline & C.V. (\%) & 6.8 & 5.9 & 15 & 12.1 & 20.9 & 17.1 & 13.7 & 88.2 & 46.3 & 6.8 \\
\hline \multirow[t]{4}{*}{ MLO } & Min. & 1023.4 & 1220.7 & 17 & 142.4 & 4.4 & 12.8 & 10.8 & 0.0 & 39.7 & 1023.4 \\
\hline & Max. & 1386.4 & 1374.9 & 28 & 198.8 & 11.8 & 21.6 & 18.6 & 17.2 & 59.8 & 1386.4 \\
\hline & Mean & $1253.5^{\mathrm{a}}$ & $1304.2^{\mathrm{ab}}$ & $21^{\mathrm{a}}$ & $171.2^{\mathrm{a}}$ & $8.6^{\mathrm{a}}$ & $17.8^{\mathrm{a}}$ & $15.0^{\mathrm{ab}}$ & $7.2^{\mathrm{a}}$ & $51.4^{\mathrm{a}}$ & $1253.5^{\mathrm{a}}$ \\
\hline & C.V. (\%) & 7.7 & 4.3 & 13 & 10.7 & 26.7 & 14.1 & 15.2 & 77.2 & 12.8 & 7.7 \\
\hline
\end{tabular}

Means followed by the same letter in each column are statistically equal according to the Hochberg's GT2 test, at $5 \%$.

$B L R=$ reaction wood in the base; $B L O=$ opposite wood in the base; $M L R=$ reaction wood in the middle; $M L O=$ opposite wood in the middle.

Médias seguidas da mesma letra em cada coluna são estatisticamente iguais segundo o teste de Hochberg 's GT2, a5\%.

$B L R=$ lenho de reação na base; $B L O=$ lenho oposto na base; $M L R=$ lenho de reação no meio; $M L O=$ lenho oposto no meio; $B F G$ = fibra gelatinosa na base.

Table 3 -Cluster centers and the most representative groups within the clusters

Tabela 3 -Centros de cluster e grupos mais representativos dentro dos clusters.

\begin{tabular}{|c|c|c|c|c|c|c|c|c|c|c|c|c|}
\hline \multirow[t]{2}{*}{ Cluster } & \multicolumn{12}{|c|}{ Variáveis } \\
\hline & $\begin{array}{c}\text { Tam. } \\
(\%)\end{array}$ & $\begin{array}{l}\text { Len. } \\
\text { NF } \\
(\mu \mathrm{m})\end{array}$ & $\begin{array}{c}\text { Len. } \\
\text { GF } \\
(\mu \mathrm{m})\end{array}$ & $\begin{array}{c}\text { MFA } \\
\left({ }^{\circ}\right)\end{array}$ & $\begin{array}{l}\text { Vessel } \\
\text { diam. } \\
(\mu \mathrm{m})\end{array}$ & $\begin{array}{c}\text { Prop. } \\
\text { Vessel } \\
(\%)\end{array}$ & $\begin{array}{c}\text { Prop. } \\
\text { RP } \\
(\%)\end{array}$ & $\begin{array}{l}\text { Prop. } \\
\text { AP } \\
(\%)\end{array}$ & $\begin{array}{c}\text { Prop. } \\
\text { NF } \\
(\%)\end{array}$ & $\begin{array}{c}\text { Prop. } \\
\text { GF } \\
(\%)\end{array}$ & $\begin{array}{l}\text { Len. } \\
\text { NF } \\
(\mu \mathrm{m})\end{array}$ & $\begin{array}{l}\text { Len. } \\
\text { FN } \\
(\mu \mathrm{m})\end{array}$ \\
\hline 1 & 63.4 & 1244.21 & 1297.26 & 20.31 & 172.86 & 0.08 & 0.18 & 0.14 & 0.10 & 0.50 & 1244.21 & 1297.26 \\
\hline 2 & 36.6 & 1250.99 & 1356.38 & 20.44 & 181.48 & 0.1 & 0.18 & 0.16 & 0.23 & 0.33 & 1250.99 & 1356.38 \\
\hline
\end{tabular}
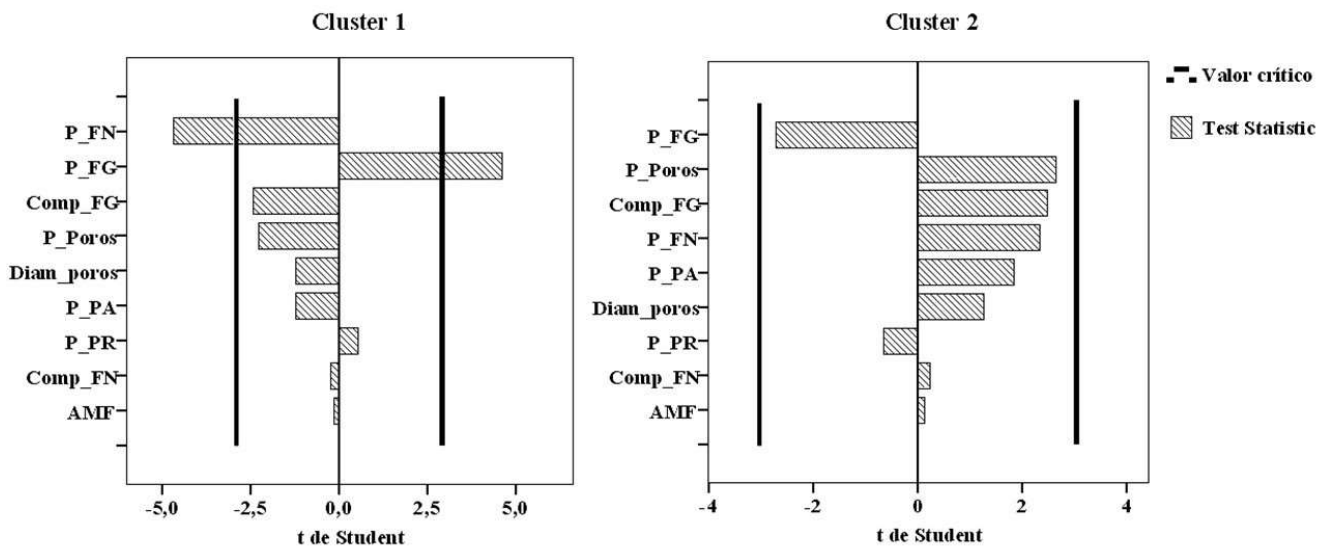

Figura 1 - Classificação das variáveis dentro de cada cluster por ordem de importância.

Figure 1 - Classification of features within each cluster in order of importance. 
The base (BFG) and middle (MFG) regions of the trunk had a large presence of gelatinous fibers, and had lower averages for the tangential diameter of vessel elements than the other groups. There was also a predominance of non-gelatinous fibers (Table 4). The post hoc comparison by Hochberg GT2 test indicated that the BFG average $(157.97 \mu \mathrm{m})$ was significantly different from the others. Despite also not presenting a higher average than the BFG, the MFG Group $(166.45 \mu \mathrm{m})$ was considered similar to groups with higher averages.

\section{DISCUSSION}

Different characteristics from those commonly observed in studies of tension wood in other species were observed in rubber trees. Species such as Populus sp. and Leucaena leucocephala, which only present tension wood at the top of trunk and branch inclinations are often found in literature (JOUREZ; RIBEAUX; LECLERQ, 2001; COUTAND et al., 2004; PRAMOD; RAO; SUNDBERG, 2013).

The presence of gelatinous fibers is another important factor to highlight. Species such as Magnolia obovata and M.kobus, for example, display tension wood without the formation of gelatinous fibers, similar to the tension wood of conifers (YOSHIZAWA et al., 2000); thus indicating that the characteristics of this wood type may vary according to the species, as well as being associated to evolutionary aspects.

The means of non-gelatinous fiber lengths (Comp. FN) presented similar values between groups (trunk regions), as well as for microfibril angle (AMF). However, the variables of proportionality were those that had the most differences between the groups, especially the gelatinous (Prop. FN) and non-gelatinous (Prop. FG) fiber proportions. These are variables that behave inversely; that is, when the values of one increase, the other consequently decreases.
All fiber length values seen here are similar to those found by Severo et al. (2013) for the same species. They found values ranging from $1250 \mu \mathrm{m}$ (juvenile wood) to $1500 \mathrm{im}$ (adult wood). Overall, fibers in the middle of the trunk for both tension and opposite wood had greater lengths of fibers than at the base, although those are commonly smaller (ZOBEL; VAN BUIJTENEN, 1989).

The longer lengths were observed for tension wood at mid-trunk (MLR). Gelatinous fibers are usually larger than non-gelatinous fibers (ZOBEL; VAN BUIJTENEN, 1989). Some studies indicate that the increase in length of gelatinous fibers is influenced by the formation of tension wood (JOUREZ; RIBEAUX; LECLERQ, 2001; PANDE, 2013). Eccentric growth of the trunk can be a result from increased duration of cell division or division rate in the vascular cambium, and this can cause the fiber length in the tension region to be higher or shorter than normal wood. In some cases, it is known that the exchange activity lasts longer on the reaction side (WARDROP, 1964), which may cause the increase in fiber lengths in this region.

In many species the tension wood which is characterized by the presence of gelatinous fibers is restricted to the top of the trunks' and branches' inclination(JOUREZ, 1997, 2001; FISHER; TOMLINSON, 2002; LEHRINGER et al., 2009). There are cases of tension wood formed in the lower portion of the inclination and in non-inclined trees (CÔTÉ et al., 1969).

The gelatinous fiber was widely distributed in the trunk, being observed in the tension and opposite wood regions both at the base and mid-trunk. This diffuse distribution is evidenced by the high variation in the gelatinous and non-gelatinous fiber proportions. The region called opposite wood also showed higher average for gelatinous fiber proportion than the tension wood region, both at the base and at mid-trunk.

Table 4 - Descriptive Statistics for groups of tangential vessel diameter.

Tabela 4 - Estatísticas descritivas para os grupos de diâmetro tangencial dos elementos de vaso.

\begin{tabular}{lccc}
\hline Group & Minimum $(\boldsymbol{\mu m})$ & Maximum $(\boldsymbol{\mu m})$ & Mean \pm standard deviation $(\boldsymbol{\mu m})$ \\
\hline BSFG & 108.55 & 260.29 & $171.53^{\mathrm{a}} \pm 31.21$ \\
BFG & 94.65 & 245.52 & $157.97^{\mathrm{b}} \pm 30.70$ \\
MSFG & 100.52 & 274.53 & $171.43^{\mathrm{a}} \pm 35.42$ \\
MFG & 85.05 & 245.99 & $166.45^{\mathrm{a}} \pm 31.94$ \\
\hline
\end{tabular}

Means followed by the same letter in each column are statistically equal according to the Hochberg's GT2 test, at $5 \%$.

$\mathrm{BSFG}=$ non-gelatinous fiber in the base; $\mathrm{MFG}=$ gelatinous fiber in the middle; $\mathrm{MSFG}=$ non-gelatinous fiber in the middle

Médias seguidas da mesma letra em cada coluna são estatisticamente iguais segundo o teste de Hochberg's GT2, a5\%.

$B S F G=$ fibra não-gelatinosa na base; $M F G=$ fibra gelatinosa no meio; MSFG = fibra não-gelatinosa no meio.

Revista Árvore, Viçosa-MG, v.40, n.6, p.1099-1107, 2016 
The structural differences and hence of other properties among the wood types can cause problems in processing logs which contain large amounts of tension wood. Their presence, even in small amounts, also contributes to these problems, where tension wood is classified as a defect (VIDAURRE et al., 2013). The presence of different wood types on a board/plank, for example, can cause non-uniform effects on wood properties. Non-uniform shrinkage can cause problems such as warping and decreased resistance to wood pieces (WIMMER; JOHANSON, 2014).

MLO and MLR groups were the ones that most influenced the division of clusters, where MLR was practically alone in cluster 2 due to the set of characteristics evaluated. Tension regions tend to present different characteristics according to what has been stated above, especially in the middle trunk region. The middle of the trunk is more vulnerable to factors such as wind and crown weight/asymmetry, and it is where possible tortuosity would be more accentuated.

Something that merits attention is the higher proportion of gelatinous fibers in opposite wood, while it is usually more common to find more of this type of fiber in tension wood. Its length was smaller than in tension wood, possibly because this region is analogously compressed in a certain way to the tracheids in the compression wood in conifers, which tend to be smaller.

The largest proportion of fibers is compatible with the response obtained in the analysis of tangential vessel diameters. It was observed that the presence of intense gelatinous fibers has a negative influence, causing the latter to decrease. This difference was more pronounced at the base of the trunk, with statistical significance; however, the difference in the middle trunk region cannot be ignored.

The reduction of the tangential vessel diameter is one way of protecting those elements from cavitation and providing mechanical support for the plant, and it is also a common feature in tension wood (DICKINSON, 2000). This information makes sense when we consider the need for mechanical support associated to the very concept of tension wood. Namely, the reduction of diameter in this circumstance suggests that the plant invests more in mechanical support than liquid transport.

In addition to the physiological needs of the plant, changes in size, number and arrangement of vessels reflect in the technological aspect of the wood, and in the permeability and changes in the drying process (TOMAZELLO FILHO, 1987).

\section{CONCLUSIONS}

According to the results presented, we conclude that the evaluated anatomical characteristics differ between tension and opposite wood, and the tension region midtrunk would be more different from the others. This region is the most influenced by tensile forces, and results in greater fiber length with increased exchange activity.

Gelatinous fibers were not only present in the tension regions, but also in the opposite regions, unlike other species described in the literature. Furthermore, the proportion of this cell type was higher in opposite wood than in tension wood, but shorter. The most important characteristics for differentiating the two woods were the gelatinous fiber length and axial parenchyma.

It was possible to group the wood types according to anatomical features, especially by the following variables: gelatinous fiber length, vessel proportion, and gelatinous and non-gelatinous fiber proportions.

There was a difference in the vessel diameter between wood types, explained by the proportionality of gelatinous fibers. The fiber frequency is inversely proportional to the tangential diameter of vessel elements, especially in opposite wood, suggesting that the plant invests in more support to the detriment of liquid transport.

\section{ACKNOWLEDGEMENTS}

To the Coordination of Higher Education Personnel (CAPES) for granting research funding.

\section{REFERENCES}

BUKATSCH, F. Bemerkungen zur Doppelfärbung Astrablau-Safranin. Mikrokosmos, v.61, n.8, p.255, 1972.

CONEGLIAN, A.; SEVERO, E.T.D. Eficácia de produtos químicos no controle do fungo manchador Botryodiplodia theobromae em madeira de Hevea. Energia na Agricultura, v.29, n.2, p.95-101, 2014.

CÔTÉ, W.A.; DAY, A.C.; TIMELL, T.E.A.

Contribution to ultrastructure of tension wood

Revista Árvore, Viçosa-MG, v.40, n.6, p.1099-1107, 2016 
fibers. Wood Science and Technology, v.3, p.257-271, 1969.

COUTAND, C.; JERONIMIDIS, G.; CHANSON, B.; LOUP, C. Comparison of mechanical properties of tension and opposite wood in Populus. Wood Science and Technology, v.38, n.1, p.11-24, 2004.

DÉJARDIN, A.; LAURANS, F.; ARNAUD, D.; BRETON, C.; PILATE, G.; LEPLÉ, J.C. Wood formation in Angiosperms. Comptes Rendus Biologies, n.333, p.325-334, 2010.

DICKINSON, W.C. Integrative plant anatomy. New York: Harcourt Academic Press, 2000 .

FISHER, J.B.; STEVENSON, J.W. Occurrence of reaction wood in branches of dicotyledons and its role in treea rchitecture. Botanical Gazette, n.142, p.82-95, 1981 .

FISHER, J.B.; TOMLINSON, P.B. Tension wood fibers are related to gravitropic movement of red mangrove (Rhizophora mangle) seedlings. Journal of plant research, v.115, n.1117, p.39-45, 2002.

FOURNIER, M.; ALMÉRAS, T.; CLAIR, B.; GRILL, J. Biomechanical action and biological functions. In: GARDINER, B.; BARNETT, J.; SARANPÄÄ, P.; GRIL, J. The biology of reaction wood. Berlin: Springer-Verlag, 2014

JOUREZ, B. Le bois de tension 1. Définition et distributiondansl'arbre. Biotechnology, Agronomy, Society and Environment, v.1, n.2, p.100-112, 1997.

JOUREZ, B.; RIBOUX, A.; LECLERQ, A. Anatomical characteristics of tension wood and opposite wood in young inclined trunks of poplar (Populus euramericana CV "Ghoy"). IAWA Journal, v.22, n.2, p.133-157, 2001.

LEHRINGER, C.; DANIEL, G.; SCHMITT, U. TEM/ FE-SEM studies on tension wood fibres of Acer spp., Fagus sylvatica L. and Quercus robur L. Wood Science and Technology, v.43, n.78, p.691-702, 2009.

LIM, S. Tension wood in rubberwood. Timber Technology Bulletin, n.5, p.1-3, 1998.
LUCHI, A.E. Anatomia do lenho de Croton urucurana Baill. (Euphorbiaceae) de solos com diferentes níveis de umidade. Revista

Brasileira de Botânica, v.27, n.2, p.271-280, 2004.

MATAN, N.; MATAN, N.; KETSA, S. Effect of heat curing on antifungal activities of anise oil and garlic oil against Aspergillus niger on rubberwood. International Biodeterioration and Biodegradation, v.75, p.150-157, 2012.

NAKAGAWA, K.; YOSHINAGA, A.; TAKABE, K. Xylan deposition and lignification in the multilayered cell walls of phloem fibres in Mallotus japonicus (Euphorbiaceae). Tree Physiology, v.34, n.9, p.1018-1029, 2014.

NASSAR, N.M.A.; ABREU, L.F.A.; TEODORO, D.A.P.; GRACIANO-RIBEIRO, D. Drought tolerant trunk anatomy characteristics in Maniho esculenta (Euphorbiaceae) and a wild relative. Genetics and Molecular Research, v.9, n.2, p.1023-1031, 2010.

NOBUCHI, T.; MUNIANDY, D.; SAHRI, M.H. Formation and anatomical characteristics of tension wood in plantation-grown Hevea brasiliensis (Willd.) Muell.-Arg. Malaysian Forester, v.74, p.133-142, 2011.

OKINO, E.Y.A.; SOUZA, M.R.D.; SANTANA, M.A.E.; SOUSA, M.E.D.; TEIXEIRA, D.E. Chapa aglomerada de cimento-madeira de Hevea brasiliensisMüll. Arg. Revista Árvore, v.28, n.3, p.451-457, 2004.

OKINO, E.Y.A.; TEIXEIRA, D.E.; SOUZA, M.R.; SANTANA, M.A.E.; SILVA, C.B.G.; TOMAZ, R.B.; SOUSA, M.E. Uso das madeiras de seringueira, pinus e cipreste na fabricação de chapas OSB. Floresta, v.39, n.2, p.457-468, 2009

PANDE, P.K. Influence of growth, wood anatomical properties and specific gravity on heartwood, sapwood and tension-wood in Dalbergia sissoo Roxb. Journal of the Indian Academy of Wood Science, v.10, n.1, p.16-21, 2013.

PRAMOD, S.; RAO, K.S.; SUNDBERG, A Structural, histochemical and chemical

Revista Árvore, Viçosa-MG, v.40, n.6, p.1099-1107, 2016 
characterization of normal, tension and opposite wood of Subabul (Leucaena leucocephala (lam.) De wit.). Wood Science and Technology, v.47, n.4, p.777-796, 2013.

RATNASINGAM, J.; GROHMANN, R. Super heated steam application to optimize the kiln drying of rubberwood (Hevea brasiliensis).

European Journalof Wood and Wood Products, v.73, n.3, p.407-409, 2015.

RATNASINGAM, J.; MA, T. Optimizing the cutting of tension wood in rubberwood: An economic and quality perspective. Journal of Applied Sciences, v.10, n.20, p.2454-2458, 2010.

SEVERO, E.T.D.; OLIVEIRA JR, E.F.; SANSIGOLO, C.A.; ROCHA, C.D.; CALONEGO, F.W. Properties of juvenile and mature woods of Hevea brasiliensis untapped and with tapping panels. European Journal of Wood and Wood Products, v.71, n.6, p.815-818, 2013.

SHUKLA, S.R.; SHARMA, S.K. Effect of high temperature processing under different environments on physical and surface properties of rubberwood (Hevea brasiliensis). Journal of the Indian Academy of Wood Science, v.11, n.2, p.182-189, 2014.

SIEGLOCH, A.M.; MARCHIORI, J.N.C.; SANTOS, S.R. Espécies ornamentais de Euphorbia.
Floresta, v.43, n.4, p.643-652, 2013.

TOMAZELLO FILHO, M. Variação radial da densidade básica e da estrutura anatômica da madeira do Eucalyptus globulus, E. pellita e E. acmenioides. Revista IPEF, n.36, p.35-42, 1987.

VIDAURRE, G.B.; LOMBARDI, L.R.; NUTTO, L.; FRANCA, F.J.N.; OLIVEIRA, J.T.S.; ARANTES, M.D.C. Propriedades da madeira de reação.

Floresta e Ambiente, v.20, n.1, p.26-37, 2013.

WARDROP, A.B. Reaction anatomy of arborescent Angiosperms. In: ZIMMERMANN, M.H. The formation of wood in forest trees. New York: Academy Press, 1964. p.562.

WIMMER, R.; JOHANSON, M. Effects of reaction wood on the performance of wood and woodbased products. In: GARDINER, B.; BARNETT, J.; SARANPÄ̈̈, P.; GRIL, J. The biology of reaction wood. Berlin: Springer-Verlag, 2014.

YOSHIZAWA, N.; INAMI, A.; MIYAKE, S.; ISHIGURI, F.; YOKOTA, S. Anatomy and lignin distribution of reaction wood in two Magnolia species. Wood Science and Technology, v.34, n.3, p.183-196, 2000.

ZOBEL, B.J.; VAN BUIJTENEN, J.P. Wood variation: Its causes and control. New York: Springer, 1989. 